NASA/TM-2007-215009
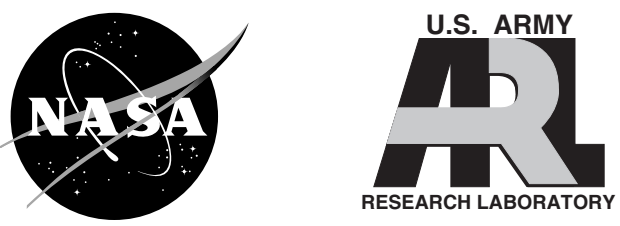

\title{
Pitting and Bending Fatigue Evaluations of a New Case-Carburized Gear Steel
}

Timothy Krantz

U.S. Army Research Laboratory, Glenn Research Center, Cleveland, Ohio

Brian Tufts

QuesTek Innovations, LLC, Evanston, Illinois 


\section{NASA STI Program . . . in Profile}

Since its founding, NASA has been dedicated to the advancement of aeronautics and space science. The NASA Scientific and Technical Information (STI) program plays a key part in helping NASA maintain this important role.

The NASA STI Program operates under the auspices of the Agency Chief Information Officer. It collects, organizes, provides for archiving, and disseminates NASA's STI. The NASA STI program provides access to the NASA Aeronautics and Space Database and its public interface, the NASA Technical Reports Server, thus providing one of the largest collections of aeronautical and space science STI in the world. Results are published in both non-NASA channels and by NASA in the NASA STI Report Series, which includes the following report types:

- TECHNICAL PUBLICATION. Reports of completed research or a major significant phase of research that present the results of NASA programs and include extensive data or theoretical analysis. Includes compilations of significant scientific and technical data and information deemed to be of continuing reference value. NASA counterpart of peer-reviewed formal professional papers but has less stringent limitations on manuscript length and extent of graphic presentations.

- TECHNICAL MEMORANDUM. Scientific and technical findings that are preliminary or of specialized interest, e.g., quick release reports, working papers, and bibliographies that contain minimal annotation. Does not contain extensive analysis.

- CONTRACTOR REPORT. Scientific and technical findings by NASA-sponsored contractors and grantees.
- CONFERENCE PUBLICATION. Collected papers from scientific and technical conferences, symposia, seminars, or other meetings sponsored or cosponsored by NASA.

- SPECIAL PUBLICATION. Scientific, technical, or historical information from NASA programs, projects, and missions, often concerned with subjects having substantial public interest.

- TECHNICAL TRANSLATION. Englishlanguage translations of foreign scientific and technical material pertinent to NASA's mission.

Specialized services also include creating custom thesauri, building customized databases, organizing and publishing research results.

For more information about the NASA STI program, see the following:

- Access the NASA STI program home page at http://www.sti.nasa.gov

- E-mail your question via the Internet to help@sti.nasa.gov

- Fax your question to the NASA STI Help Desk at 301-621-0134

- Telephone the NASA STI Help Desk at 301-621-0390

- Write to: NASA Center for AeroSpace Information (CASI) 7115 Standard Drive Hanover, MD 21076-1320 
NASA/TM-2007-215009
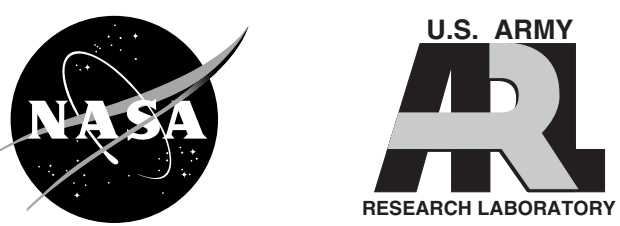

\section{Pitting and Bending Fatigue Evaluations of a New Case-Carburized Gear Steel}

Timothy Krantz

U.S. Army Research Laboratory, Glenn Research Center, Cleveland, Ohio

Brian Tufts

QuesTek Innovations, LLC, Evanston, Illinois

Prepared for the

International Design Engineering Technical Conferences and Computers and Information in Engineering Conference

sponsored by the American Society of Mechanical Engineers

Las Vegas, Nevada, September 4-7, 2007

National Aeronautics and

Space Administration

Glenn Research Center

Cleveland, Ohio 44135 
Trade names and trademarks are used in this report for identification only. Their usage does not constitute an official endorsement, either expressed or implied, by the National Aeronautics and Space Administration.

Level of Review: This material has been technically reviewed by technical management.

Available from

NASA Center for Aerospace Information 7115 Standard Drive

Hanover, MD 21076-1320
National Technical Information Service 5285 Port Royal Road Springfield, VA 22161 


\title{
Pitting and Bending Fatigue Evaluations of a New Case-Carburized Gear Steel
}

\author{
Timothy Krantz \\ U.S. Army Research Laboratory \\ Glenn Research Center \\ Cleveland, Ohio 44135 \\ Brian Tufts \\ QuesTek Innovations, LLC \\ Evanston, Illinois 60201
}

\begin{abstract}
The power density of a gearbox is an important consideration for many applications and is especially important for gearboxes used on aircraft. One approach to improving power density of gearing is to improve the steel properties by design of the alloy. The alloy tested in this work was designed to be case-carburized with surface hardness of Rockwell C66 after hardening. Test gear performance was evaluated using surface fatigue tests and single-tooth bending fatigue tests. The performance of gears made from the new alloy was compared to the performance of gears made from two alloys currently used for aviation gearing. The new alloy exhibited significantly better performance in surface fatigue testing, demonstrating the value of the improved properties in the case layer. However, the alloy exhibited lesser performance in single-tooth bending fatigue testing. The fracture toughness of the tested gears was insufficient for use in aircraft applications as judged by the behavior exhibited during the single tooth bending tests. This study quantified the performance of the new alloy and has provided guidance for the design and development of next generation gear steels.
\end{abstract}

\section{Introduction}

The power density of a gearbox is an important consideration for many applications and is especially important for gearboxes used on aircraft. The gearbox power density is limited by ability of the gear teeth to transmit power for the required number of cycles without pitting, spalling, or fatigue in the root-fillet region (bending fatigue). Methods for improving fatigue life capabilities of gears are highly desirable. Significant research has been conducted to develop new alloys and new steel processing techniques to improve the performance of mechanical components (refs. 1 and 2).

The subject of this report is the fatigue performance of gears made from a relatively new steel alloy, Ferrium C69 (QuesTek Innovations, LLC). Helicopters make extensive use of two gear steels, AISI 9310 (AMS 6265) and Pyrowear 53 (AMS 6308B) (Carpenter Technology). Fatigue test data for these alloys were available and selected as baselines for purposes of comparing the performance of the gears of the present work. The alloy was selected and processed to achieve a higher surface hardness compared to production gears made from the just mentioned alloys currently in use for helicopters.

For through-hardened steels, it has been demonstrated experimentally that a higher surface hardness provides for longer surface fatigue lives (ref. 3). One might anticipate a similar benefit for case-carburized surfaces. Rakhit (ref. 4) discusses gears steels, definitions of effective case depth, and general trends of bending fatigue strength as a function of core hardness. As pointed out by Rakhit (ref. 4), the relationship of the case and core properties of gear teeth to the fatigue strength performance is an ongoing subject of study and understanding. For any given gear application using casecarburized alloys, the heat treatment processing can be used to balance the fatigue resistance of the carburized surface with needed toughness of the subsurface core. Fatigue testing is needed to quantify performance. This report documents gear testing done to evaluate the fatigue properties of gears made from a new steel alloy having a high surface hardness.

\section{Test Specimens, Apparatus, and Procedure}

\section{Test Specimens}

The dimensions of the gears are given in table 1. The gears (fig. 1) are $3.175 \mathrm{~mm}$ module ( 8 diametral pitch) and have a standard $20^{\circ}$ involute pressure angle with tip relief of $0.013 \mathrm{~mm}(0.0005$ in.) starting at the highest point of single tooth contact. The nominal face width is $6.35 \mathrm{~mm}(0.250 \mathrm{in}$.), and the gears have a nominal $0.13-\mathrm{mm}-(0.005$-in.-) radius edge break to avoid edge loading.

The gears of the present study were made from Ferrium C69 alloy. After completion of all heat treatment and grinding operations, a gear was cut and a tooth was removed for microstructural characterization. The microstructure of the near-surface material is provided in figure 2 . The surface was etched in 2 percent nital. The gear tooth has a uniform lath martensitic structure. Micro-hardness was measured in both the root and flank locations. Vickers hardness measurements were made, and the results were converted to Rockwell C scale. Figure 3 provides the measured hardness as a function of depth from the surface for the flank location. 
TABLE 1.-SPUR GEAR DATA

[Gear Tolerance per AGMA 2000-A88 Class 12)

\begin{tabular}{|lr|}
\hline Number of teeth & 28 \\
\hline Module, mm & 3.175 \\
\hline Diametral pitch & 8 \\
\hline Circular pitch, mm (in.) & $9.975(0.3927)$ \\
\hline Whole depth, mm (in.) & $7.62(0.300)$ \\
\hline Addendum, mm (in.) & $3.18(.125)$ \\
\hline $\begin{array}{l}\text { Chordal tooth thickness reference, } \\
\text { mm (in.) }\end{array}$ & $4.85(0.191)$ \\
\hline Tooth width, mm (in.) & $6.35(0.25)$ \\
\hline Pressure angle, deg. & 20 \\
\hline Pitch diameter, mm (in.) & $98.90(3.500)$ \\
\hline Outside diameter, mm (in.) & 1.02 to 1.52 \\
\hline Root fillet, mm (in.) & $(0.04$ to 0.06$)$ \\
\hline Measurement over pins, mm (in.) & 96.03 to 96.30 \\
& $(3.7807$ to 3.7915$)$ \\
\hline Pin diameter, mm (in.) & $5.49(0.216)$ \\
\hline Backlash reference, mm (in.) & $0.254(0.010)$ \\
\hline Tip relief, mm (in.) & 0.010 to 0.015 \\
& $(0.0004$ to 0.0006$)$ \\
\hline
\end{tabular}

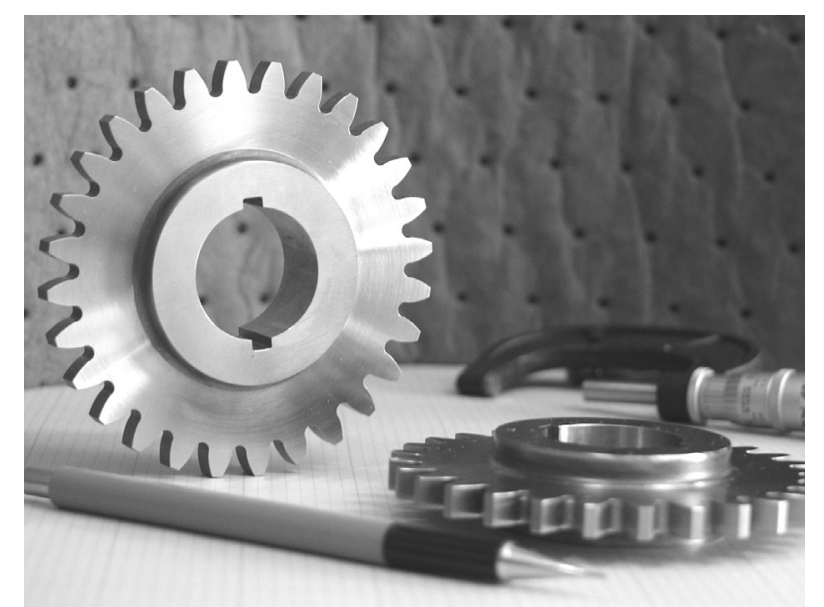

Figure 1.-Gears for surface fatigue testing on the NASA Glenn Research Center gear fatigue test apparatus.

\section{Gear Test Apparatus for Surface Fatigue}

The gear surface fatigue tests were performed in the NASA Glenn Research Center's gear test apparatus. The test rig is shown in figure 4(a) and is described in reference 5. The rig uses the four-square principle of applying test loads so that the input drive only needs to overcome the frictional losses in the system. The test rig is belt driven and the variable speed motor was operated at a fixed speed for the subject testing.

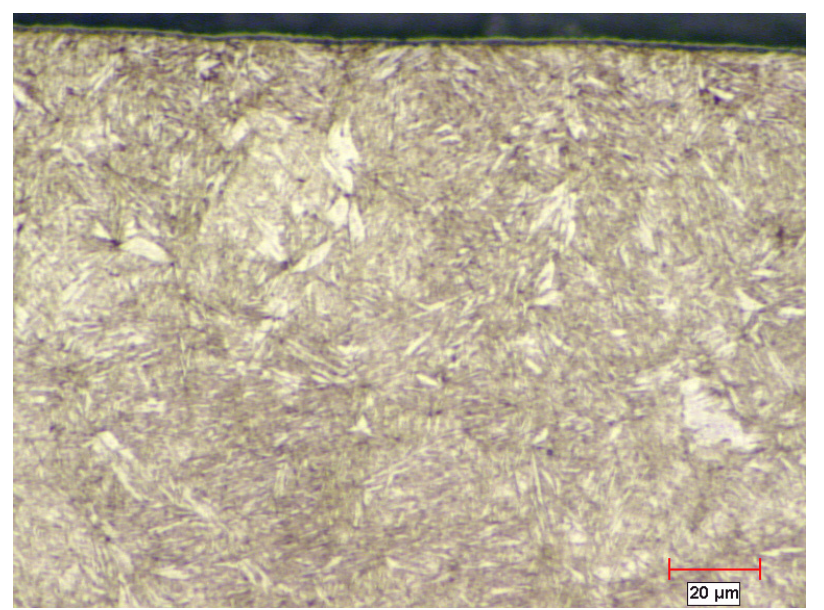

Figure 2.-Microstructure of a Ferrium C69 ${ }^{\mathrm{TM}}$ test gear, microphotograph prepared with $2 \%$ nital solution.

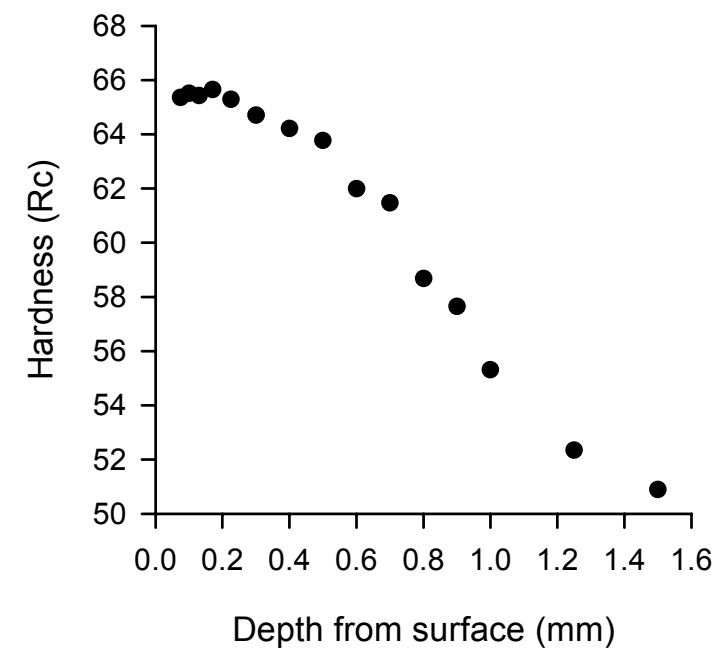

Figure 3.-Measured hardness of a Ferrium ${ }^{\mathrm{TM}} \mathrm{C} 69$ test gear tooth. The data are an average value of three measurements made at each reported depth.

A schematic of the testing apparatus is shown in figure 4(b). Oil pressure and leakage replacement flow is supplied to the load vanes through a shaft seal. As the oil pressure is increased on the load vanes located inside one of the slave gears, torque is applied to its shaft. This torque is transmitted through the test gears and back to the slave gears. In this way, power is re-circulated and the desired load and corresponding stress level on the test gear teeth may be obtained by adjusting the hydraulic pressure. The two identical test gears may be started under no load, and the load can then be applied gradually. This arrangement has the feature that changes in load do not affect the width or position of the running track on the gear teeth. The gears are tested with the faces offset as shown in figure 4. By making use of the offset arrangement, the desired contact stress can be achieved within the torque capacity of the testing machine. Because of the offset testing arrangement, four tests can be completed for each pair of gears. 

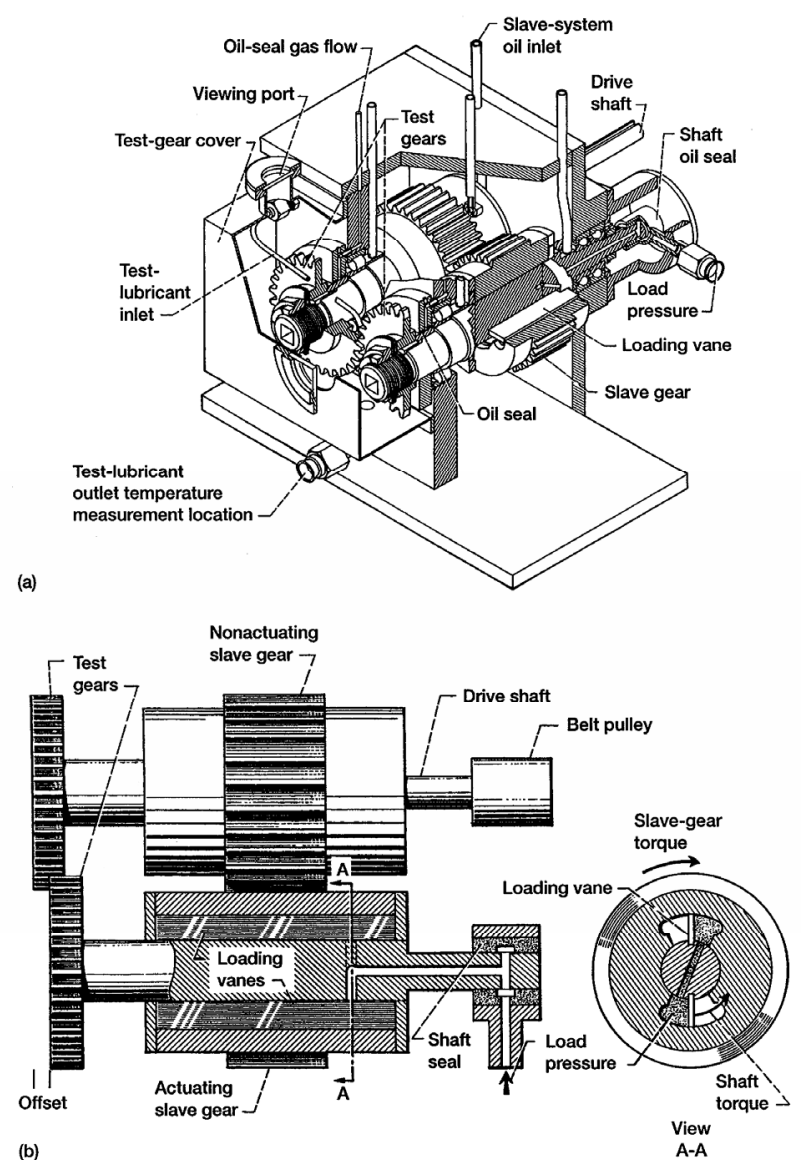

Figure 4.-NASA Glenn Research Center gear fatigue test apparatus. (a) Cutaway view. (b) Schematic view.

Separate lubrication systems are provided for the test and slave gears. The two lubrication systems are separated at the gearbox shafts by lip seals. The two lubrication systems use the same type of oil. The test gear lubricant is filtered through a $5-\mu \mathrm{m}(200-\mu \mathrm{in}$.) nominal fiberglass filter. A vibration transducer mounted on the gearbox is used to automatically stop the test rig when gear surface fatigue damage occurs. The gearbox is also automatically stopped if there is a loss of lubricant flow to either the slave gearbox or the test gears or if the lubricant overheats.

\section{Gear Testing Apparatus for Bending Fatigue}

The gear bending fatigue tests were performed in the NASA Glenn Research Center Fatigue Lab using a commercially available fatigue test machine with a special fixture specifically designed to load the test gear tooth at the highest point of single tooth contact. The fatigue test machine used for this investigation was a servo-hydraulic test system with $20,000 \mathrm{lb}$. load capacity. With the exception of the gear test assembly, the test system was in standard configuration for fatigue testing smooth shank, cylindrical specimens. The load mechanism features an alignment fixture which can be used for closely controlled positional and angular adjustments. A load cell was used for control purposes and to monitored the test loads. The gear test assembly is mounted in the load frame using a support arm which is attached to the two-post load frame. The bottom grip is attached to the actuator which serves to power the system using 3000 psi oil supplied by a central hydraulic system. An AC type linear variable differential transformer (LVDT) is attached to the base of the load frame was used to measure actuator displacement or stroke. The stroke was monitored throughout the test for quality control purposes.

\section{Test Procedure for Surface Fatigue Testing}

The gears were lubricated with a single batch of synthetic paraffinic oil. Physical properties of this lubricant are summarized in table 2. Five percent of extreme pressure additive with partial contents including phosphorus and sulfur was added to the lubricant. This lubricant has been used extensively for gear fatigue testing in the NASA Glenn spur gear fatigue rigs. For example, Krantz (ref. 6) reported results of 146 tests using this same oil (termed "NASA standard" in the referenced article) to evaluate the surface fatigue lives of AISI 9310 steel gears. The oil and additive mixture used in this work is similar to 5-centistoke oils used for helicopter main rotor gearboxes.

\section{TABLE 2.--LUBRICANT PROPERTIES}

\begin{tabular}{|lr|}
\hline Additive & ${ }^{\mathrm{a}}$ Lubrizol 5002 \\
Kinematic viscosity, cSt & \\
$311 \mathrm{~K}\left(100^{\circ} \mathrm{F}\right)$ & 31.6 \\
$372 \mathrm{~K}\left(210^{\circ} \mathrm{F}\right)$ & 5.7 \\
Specific gravity & 0.83 \\
Flash point, $\mathrm{K}\left({ }^{\circ} \mathrm{F}\right)$ & $544(520)$ \\
Pour point, $\mathrm{K}\left({ }^{\circ} \mathrm{F}\right)$ & $211(-80)$ \\
\hline
\end{tabular}

${ }^{a}$ Partial content of additive: phosphorus, $0.6 \mathrm{wt} \%$; sulfur, $18.5 \mathrm{wt} \%$

The test gears were run with the tooth faces offset by a nominal $3.3 \mathrm{~mm}(0.130 \mathrm{in}$.) to give a surface load width on the gear face of $3.0 \mathrm{~mm}(0.118 \mathrm{in})$. The actual tooth face offset for each test is based on the measured face width of the test specimen, and the offset is verified upon installation using a depth gage. The nominal $0.13-\mathrm{mm}-(0.005$ - in.-) radius edge break is allowed for to calculate load intensity. All tests were run-in at a load (normal to the pitch circle) per unit width of $123 \mathrm{~N} / \mathrm{mm}(700 \mathrm{lb} / \mathrm{in}$.) for 1 hour. The load was then increased to $587 \mathrm{~N} / \mathrm{mm}(3350 \mathrm{lb} / \mathrm{in}$.), which resulted in a 1.72-GPa (250-ksi) pitch-line maximum Hertz stress. At the pitch-line load, the tooth bending stress was $0.21 \mathrm{GPa}(30 \mathrm{ksi})$ if plain bending was assumed. However, because there was an offset load, there was an additional stress imposed on the tooth bending stress. The combined effects of the bending and torsional moments yield a maximum stress of $0.26 \mathrm{GPa}$ (37 ksi). The effects of tip relief and dynamic load were not considered for the calculation of stresses. The dynamic tooth 
forces on the gear teeth for test gears made to geometry specifications consistent with the present work have been previously reported (ref. 6).

The gears were tested at $10000 \mathrm{rpm}$ which gave a pitchline velocity of $46.5 \mathrm{~m} / \mathrm{s}(9154 \mathrm{ft} / \mathrm{min})$. Inlet and outlet oil temperatures were continuously monitored. Lubricant was cooled and supplied to the inlet of the gear mesh. The lubricant outlet temperature was recorded and observed to have been maintained at $349 \pm 5 \mathrm{~K}\left(169 \pm 7^{\circ} \mathrm{F}\right)$ once the rig was running and the temperatures were stabilized. The tests ran continuously ( $24 \mathrm{hr} /$ day) until a vibration detection transducer automatically stopped the rig. The transducer is located on the gearbox adjacent to the test gears. Also, the surfaces of the teeth on the driven gear were inspected at regular intervals (normally not exceeding 50 million cycles between inspections) to verify the absence of surface fatigue. The lubricant was circulated through a $5-\mu \mathrm{m}-(200-\mu$ in.-) nominal fiberglass filter to remove wear particles. For each test, 3.8 liter (1 gal) of lubricant was used. Six identical test rigs were used in this work. The pairing of gear samples and the run order was done randomly to minimize rig-to-rig and temporal differences.

The film thickness at the pitch point for the operating conditions of the surface fatigue testing was calculated using the computer program EXTERN. The computing tool is an implementation of the methods of references 7 and 8 . For the purposes of the calculation, the gear surface temperature was assumed to be equal to the average of the oil inlet and outlet temperatures. Using the stated assumptions, the calculated pitch-line film thickness is $0.54 \mu \mathrm{m}(21 \mu \mathrm{in})$.

\section{Test Procedure for Single Tooth Bending Fatigue Testing}

The gear test assembly is depicted in figure 5. The gear test specimen is positioned on a shaft which is a press fit in the fixture's casing. The test assembly was designed to conduct tests on gear teeth in sets of three. This approach was adopted in part to provide the necessary clearance for the two load rods. To permit access to the gear tooth to be tested several teeth nearby needed to be removed. Teeth were removed using the Electrode Discharge Machining (EDM) process. The upper load rod contacts the reaction gear tooth near the root of the tooth. In contrast, the lower load rod contacts the test gear tooth at the highest point of single tooth contact. Adopting this approach, highest bending stresses are introduced into the test gear tooth and the location of fatigue failure is predetermined with a high degree of confidence. The rotational orientation of the test gear is precisely established using setup tooling. The rod that loads the test tooth at the highest point of single tooth contact is representative of a rack gear (flat profile or infinite radius of curvature) contacting the test tooth.

A check of the fixture alignment was made using machinists dye (bluing) applied to the gear tooth profile prior to testing. The dye removal created by the load rod contact areas gave a clear indication that uniform load distributions on

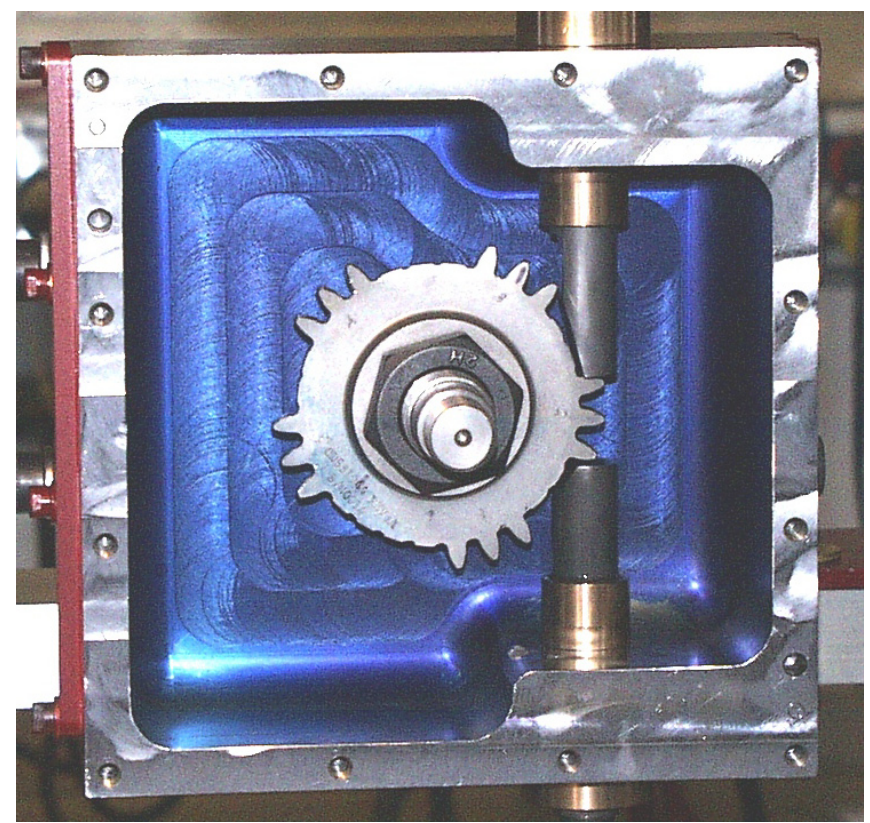

Figure 5.-Test gear installed in test fixture, cover removed for photograph.

both gear teeth had been achieved. The contact pattern procedure was followed in all tests with excellent results.

The single tooth bending tests of this study were conducted using unidirectional loading. Testing was done in load control. The gear was positioned to provide load on the test tooth at the theoretical highest point of single tooth contact for the case of the test gear mating with an identical gear at the standard center distance (radius of $44.30 \mathrm{~mm}$ (1.774 in.)). The load is cycled from a small, minimum load to the maximum load desired for the given fatigue test. The load range was maintained a constant value throughout the test. Loading was cycled at $0.5 \mathrm{~Hz}$ using a sinusoidal waveform. Crack initiation was defined to occur when the loading rod stroke increased approximately 2 percent $(\sim 0.0002$ in. change) relative to the stroke for the gear tooth at test initiation.

\section{Results and Discussion}

\section{Surface Fatigue Test Results.}

Surface fatigue testing was completed on a set of gears manufactured from Ferrium C69 steel. The set of gears were case-carburized and ground. The test conditions were a load per unit width of $587 \mathrm{~N} / \mathrm{mm}(3350 \mathrm{lb} / \mathrm{in}$.), which resulted in a 1.72-GPa (250-ksi) pitch-line maximum Hertz stress. For purposes of this work, failure was defined as one or more visible spalls or pits that can also be detected by tracing over the pit with a sharp stylus. The visual appearance of the surface fatigue (fig. 6) was typical of other alloys tested in the same conditions. The gears were qualitatively judged to have good wear resistance. Results of the surface fatigue testing are 


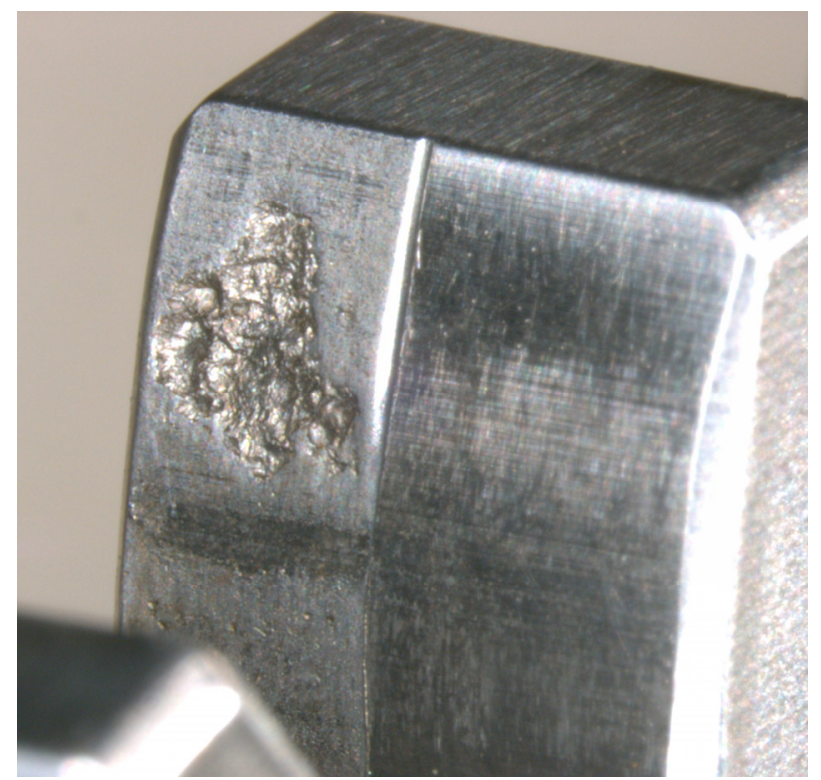

Figure 6.-Typical surface fatigue failure of the Ferrium C69 alloy.

summarized in table 3. Ten gear pair surfaces were tested. Five of the tests resulted in surface fatigue failures. The other five testes resulted in no surface fatigue and no impending indication of fatigue, and therefore can be considered as suspended tests.

The experiments conducted were accelerated life tests. That is, for a helicopter application the gears would operate at stress levels less than the stresses used for testing. Such an approach is used to economically produce surface fatigue data. To evaluate the significance of the surface fatigue test results, one can compare the results to past work done using different gear alloys but identical gear geometry specifications and test procedures. Often, fatigue test results are compared on the basis of the predicted ten-percent lives (refs. 1, 5, and 10). The present work comprised ten tests with five of the ten tests resulting in surface fatigue. An estimate of the ten-percent life from such a limited dataset provides for estimates with large statistical confidence intervals (ref. 6). Therefore, for the present work comparisons are made using estimates of the median (fifty-percent) lives. The distribution of fatigue life was modeled as a two-parameter Weibull distribution. The median life estimate was calculated by the method of Johnson (ref. 9).

Krantz (ref. 6) provided a summary of 18 sets of experiments conducted using test methods consistent with the present work, gears made from AISI 9310 steel, and various lubricants and surface treatments. Results of tests conducted using test methods consistent with the present work and using gears made from Pyrowear 53 steel have also been reported (refs. 10 and 11). Some of the referenced data are for gears having shot-peening or superfinishing treatments to improve the surface fatigue lives. To provide the most direct comparison with the present study, the data for "standardground finished" gears (no shot-peening or superfinishing of the contacting surfaces) were selected as the most appropriate baseline. Table 4 provides a comparison of the results of the present study with the results of the previous works (refs. 10 and 13). The data of table 4 are the results for the bestperforming sets of "standard-ground finished" gears made from the noted alloys and tested to date on the same gear test apparatus using the same test method. The estimated surface fatigue lives (median values) of Pyrowear 53, AISI 9310, and Ferrium C69 are 134, 200, and 361 million cycles, respectively. For contact stress of $1.7 \mathrm{GPa}$ as used in the present testing, 40 of the 54 tests of the baseline alloys exhibited surface fatigue before 300 million cycles. For the Ferrium C69 alloy, 5 of the 10 tests exceeded 300 million cycles without surface fatigue.

TABLE 3.-SURFACE FATIGUE TEST RESULTS

\begin{tabular}{|c|c|c|c|}
\hline $\begin{array}{c}\text { Test } \\
\text { Number }\end{array}$ & $\begin{array}{c}\text { Running time } \\
\text { (hours) }\end{array}$ & $\begin{array}{c}\text { Running time } \\
\text { (million of cycles) }\end{array}$ & Test Result \\
\hline 1 & 64 & 38.3 & surface fatigue \\
2 & 94 & 56.2 & surface fatigue \\
3 & 296 & 177.3 & surface fatigue \\
4 & 307 & 184.2 & no failure - suspended \\
5 & 325 & 195.1 & surface fatigue \\
6 & 566 & 339.3 & no failure - suspended \\
7 & 572 & 343.2 & surface fatigue \\
8 & 1224 & 734.4 & no failure - suspended \\
9 & 1235 & 741.0 & no failure - suspended \\
10 & 1465 & 879.0 & no failure - suspended \\
\hline & \multicolumn{2}{|c}{} \\
\hline Sum of Run Times & $\mathbf{6 1 4 7}$ & $\mathbf{3 6 8 8}$ & \\
\hline
\end{tabular}


TABLE 4.-SUMMARY AND COMPARISON OF GEAR SURFACE FATIGUE PERFORMANCE

\begin{tabular}{|l|c|c|c|}
\hline \multicolumn{1}{|c|}{ Gear Material } & Number of failures & Number of tests completed & $\begin{array}{c}\text { Median life } \\
\text { (million cycles) }\end{array}$ \\
\hline $\begin{array}{l}\text { Pyrowear } \\
\text { (ref. 10) }\end{array}$ & 15 & 21 & 134 \\
\hline $\begin{array}{l}\text { AISI 9310 } \\
\text { (ref. 13) }\end{array}$ & 25 & 33 & 200 \\
\hline $\begin{array}{l}\text { Ferrium } \\
\text { (present } \text { C69 }\end{array}$ & 5 & 10 & 361 \\
\hline
\end{tabular}

\section{Bending Fatigue Test Results}

Single tooth bending fatigue testing was completed on a set of gears manufactured from Ferrium C69 steel. The set of gears were case-carburized and ground. Testing was done using unidirectional loading and load control. Testing was done until crack initiation occurred or, in some cases at the lowest levels of test load, tests were suspending with no cracks initiated. Crack initiation was defined to occur when the loading rod stroke increased approximately 2 percent $(\sim 0.0002$ in. change) relative to the stroke for the gear tooth at test initiation.

Prior to conducting single tooth bending tests on the test gears of the present study, tests had been conducted on gears made from AISI 9310 alloy (ref. 12). In the previous work, crack initiation was defined to occur when the loading rod stroke increased approximately 2 percent $(\sim 0.0002$ in. change) relative to the stroke for the gear tooth at test initiation. At this point a crack would be initiated with a size on the order of the case depth. Additional test cycles could then be applied to the AISI 9310 gears and stable crack growth would occur until the test was terminated with a crack of length $30 \sim 50$ percent of the distance across the base of the tooth. The tooth with the fatigue crack could then be removed using a single impact load in order to observe the fracture surface. The present testing was initiated with the same definition of crack initiation in mind. However, it was observed that complete failure (removal of the tooth from the rim) occurred before a crack could grow in a stable manner to even the small size that would increase the loading stoke by 2 percent. Figure 7 provides examples of failed gear teeth. The differing crack trajectories illustrate the relatively brittle nature of the gear teeth made from the new alloy as compared to the baseline AISI 9310 gear teeth.

To express the intensity of the test loads, the maximum principle tensile stress in the fillet region was calculated using linear elastic finite element analysis (ref. 12). The finite element model geometries were adjusted to closely match the actual manufactured tooth geometries as recorded using a digital microscope including actual tooth thickness and rootfillet geometry details. The resulting stress owing to the applied load is reported herein as a stress index. It is appropriate to report test condition as a stress index since this test stress does not take into account the residual stress that exists in the case-carburized hardened gears. Furthermore, the

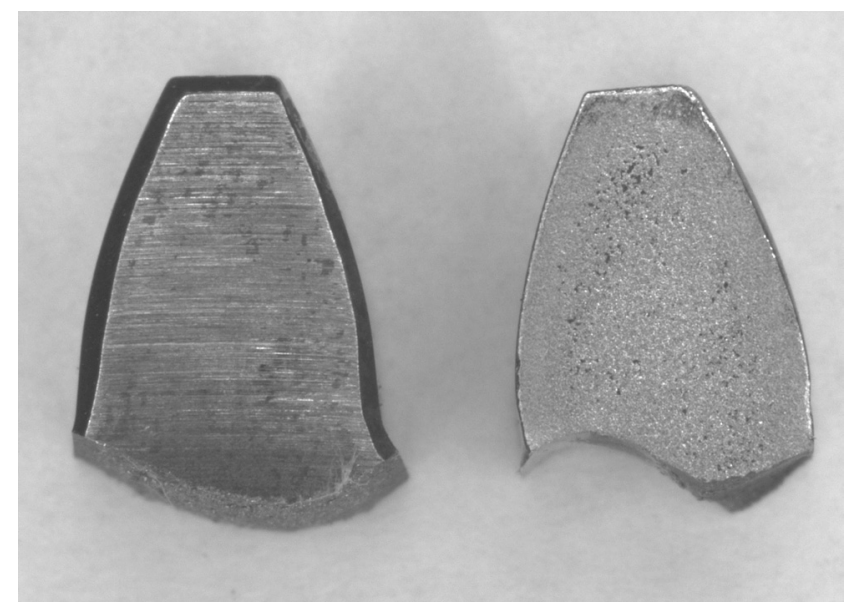

Figure 7.-Typical failed teeth after single tooth bending fatigue testing for Ferrium C69 (left) and AISI 9310 (right) steel alloys.

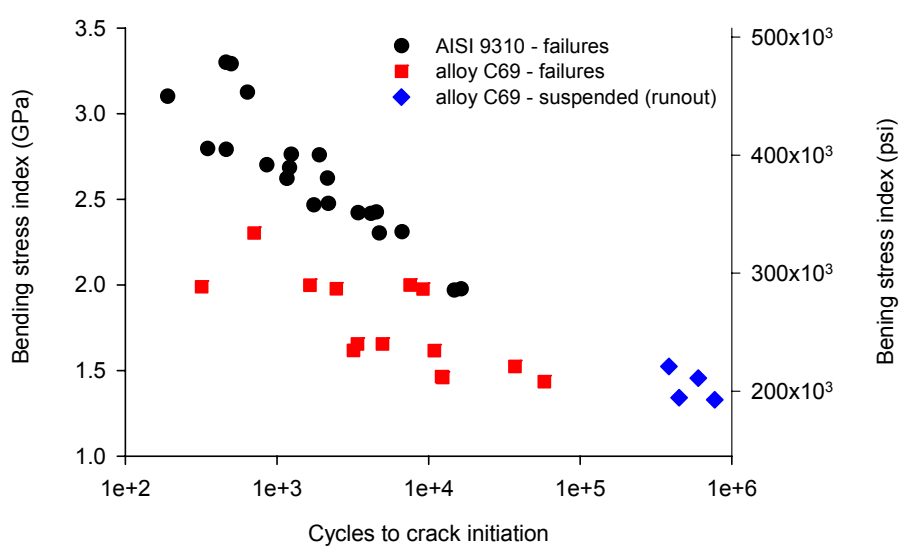

Figure 8.-Results of single tooth bending fatigue testing of Ferrium C69 and AISI 9310 steel gears (data for AISI 9310 are from ref. 12).

reported test stress owing to the applied load was calculated assuming linear elasticity, and so plasticity and nonlinear effects were not considered. The relationships of crack initiation life as a function of the stress index for the present work and previous work (ref. 12) are depicted in Figure 8 as a semi-logarithmic plot. For loads resulting in crack initiation within the cycle range 100 to 100,000 cycles, it is clear that AISI 9310 has superior performance relative to the new alloy. 
Also, the AISI 9310 exhibited excellent toughness having stable crack growth, but the new alloy exhibited brittle behavior with fast fracture occurring over essentially the full base of the tooth in all cases. For consideration as an alloy for safety-critical gear applications such as main rotor transmissions of helicopters, such brittle behavior is unacceptable. It should be noted that S-N curves for case-carburized gear teeth are often depicted as two lines on semi-logarithmic axes, one line in the region of (100 cycles $\sim 5$ million cycles) and another line for the veryhigh cycle regime ( $>\sim 500$ million cycles). The behavior of the new alloy in the very high cycle regime could not be investigated in a reasonable amount of time using the test method of this project $(0.5 \mathrm{~Hz}$ loading frequency). Note that four tests of the Ferrium C69 steel were suspended with no failure after cycle counts approaching 1 million cycles. The trends of all the data from figure 8 suggest that the Ferrium C69 gear might exhibit good performance against crack initiation in the very-high cycle regime.

This work provides some data on the behavior of the newly developed alloy. The selection of an alloy for a particular application of course requires the consideration of many properties, and the present work was not a full evaluation. For example, the scoring resistance of the new alloy was not investigated. The fracture toughness of the gear tooth is a very important for safety-critical aviation gearing, and the fracture toughness was not evaluated in this study. This study quantified some performance characteristics of the new alloy and has provided guidance for the design and development of next generation gear steels.

\section{Summary}

Gears made from steel alloy Ferrium C69 were tested using the NASA Glenn Research Center's gear test apparatus. Results of the present study were compared to past works done using the same test apparatus and test methods.

For surface fatigue testing, the present results were compared to previous works testing AISI 9310 and Pyrowear 53 (AMS 6308B), two alloys used in production today as aircraft steels. Surface fatigue testing was done at a contact stress of $1.7 \mathrm{GPa}$ (250 ksi). The Ferrium C69 provided for better surface fatigue performance relative to the production alloys.

For bending fatigue testing, the present results were compared to previous works testing AISI 9310. Testing was completed using the single tooth bending method, load control, and a crack initiation definition of a 2 percent increase in the test load stroke relative to the stroke of the initial loadings. Tests were conducted at loads that generally resulted in crack initiation in the cycle range 100 cycles to 1 million cycles. The resistance of the Ferrium C69 gears to crack initiation was less than the baseline AISI 9310 gears. The new alloy exhibited relatively brittle behavior with fast fracture occurring across essentially the full base of the tooth while the AISI 9310 test gears exhibited stable crack growth for cracks extending up to 50 percent of the tooth base.

This study quantified some performance characteristics of the new alloy and has provided guidance for the design and development of next generation gear steels.

\section{References}

1. Zaretsky, E. Editor: Tribology for Aerospace Applications, STLE SP-37, STLE, Park Ridge, Ill., 1997.

2. Beswick, J., Editor: Bearing Steel Technology, ASTM STP 1419, ASTM, West Conshohocken, PA, 2002.

3. Zaretsky, E., Parker, R., and Anderson, W.: "Effect of Component Differential Hardness on Rolling-Contact Fatigue and Load Capacity," NASA TN D-2640, 1965

4. Rakhit, A.: Heat Treatment of Gears, ASM International, Materials Park, OH, 2000.

5. Townsend, D.; Chevalier, J.; Zaretsky, E.: "Pitting Fatigue Characteristics of AISI M 50 and Super Nitralloy Spur Gears," NASA TN D-7261, (1973).

6. Krantz, T.: "The Influence of Roughness on Gear Surface Fatigue," Ph.D. Thesis, Case Western Reserve University, Cleveland, Ohio, USA, (2002).

7. Anderson, N.; Lowenthal, S.; and Black, J.: "An Analytical Method to Predict Efficiency of Aircraft Gearboxes," NASA TM-83716, AIAA Paper 84-1500, (1984).

8. Anderson, N.; Lowenthal, S.: "Spur-Gear-System Efficiency at Part and Full Load,"NASA TP-1622, (1980).

9. Johnson, L.: The Statistical Treatment of Fatigue Experiments, Elsevier Publishing Co., 1964.

10. Townsend, D.: "Surface Fatigue Life and Failure Characteristics of EX53, CBS 1000M, and AISI 9310 Gear Materials," NASA TP 2513, 1985.

11. Niskanen, P, Manesh, A. and Morgan, R.: "Reducing Wear with Superfinish Technology," AMPTIAC Quarterly, Vol. 7, No. 1, 2003.

12. Handschuh, R., Krantz, T., Lerch, B, and Burke, C.; "Investigation of Low-Cycle Bending Fatigue of AISI 9310 Steel Spur Gears," DETC2007-34095, ASME IDETC/CIE 2007, September 4-7, 2007, Las Vegas, Nevada, USA. 5.

13. Townsend, D. and Bamberger, E.: "Surface Fatigue Life of Carburized and Hardened M50NiL and AISI 9310 Spur Gears and Rolling-Contact Test Bars," NASA TM101979, AVSCOM TR 89-C-011, 1989. 


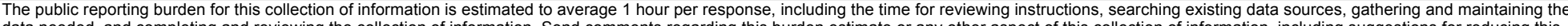

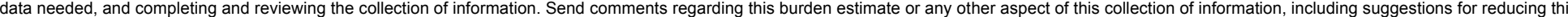

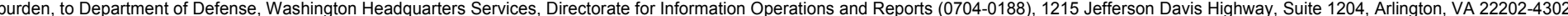

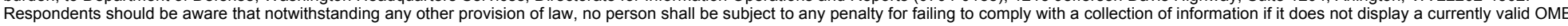
control number.

PLEASE DO NOT RETURN YOUR FORM TO THE ABOVE ADDRESS.

\section{REPORT DATE (DD-MM-YYYY) \\ 2. REPORT TYPE \\ 3. DATES COVERED (From - To)}

01-12-2007

Technical Memorandum

\section{TITLE AND SUBTITLE}

Pitting and Bending Fatigue Evaluations of a New Case-Carburized Gear Steel

5b. GRANT NUMBER

5c. PROGRAM ELEMENT NUMBER

6. AUTHOR(S)

Krantz, Timothy; Tufts, Brian

\section{5d. PROJECT NUMBER}

5e. TASK NUMBER

5f. WORK UNIT NUMBER

WBS 877868.02.07.03.01.01

8. PERFORMING ORGANIZATION

REPORT NUMBER

E-16196

National Aeronautics and Space Administration

John H. Glenn Research Center at Lewis Field

Cleveland, Ohio 44135-3191

\section{SPONSORING/MONITORING AGENCY NAME(S) AND ADDRESS(ES)}

National Aeronautics and Space Administration

Washington, DC 20546-0001

10. SPONSORING/MONITORS
ACRONYM(S)
NASA, ARL
11. SPONSORING/MONITORING
REPORT NUMBER
NASA/TM-2007-215009; ARL-TR-4123

\section{DISTRIBUTION/AVAILABILITY STATEMENT}

Unclassified-Unlimited

Subject Category: 37

Available electronically at http://gltrs.grc.nasa.gov

This publication is available from the NASA Center for AeroSpace Information, 301-621-0390

\section{SUPPLEMENTARY NOTES}

\section{ABSTRACT}

The power density of a gearbox is an important consideration for many applications and is especially important for gearboxes used on aircraft. One approach to improving power density of gearing is to improve the steel properties by design of the alloy. The alloy tested in this work was designed to be case-carburized with surface hardness of Rockwell C66 after hardening. Test gear performance was evaluated using surface fatigue tests and single-tooth bending fatigue tests. The performance of gears made from the new alloy was compared to the performance of gears made from two alloys currently used for aviation gearing. The new alloy exhibited significantly better performance in surface fatigue testing, demonstrating the value of the improved properties in the case layer. However, the alloy exhibited lesser performance in single-tooth bending fatigue testing. The fracture toughness of the tested gears was insufficient for use in aircraft applications as judged by the behavior exhibited during the single tooth bending tests. This study quantified the performance of the new alloy and has provided guidance for the design and development of next generation gear steels.

\section{SUBJECT TERMS \\ Fatigue; Gears; Steel}

\section{SECURITY CLASSIFICATION OF:}

a. REPORT

$\mathrm{U}$

\section{LIMITATION OF} ABSTRACT

18. NUMBER
OF
PAGES
13

UU

\begin{tabular}{l|l} 
PAGE & UU
\end{tabular}

19a. NAME OF RESPONSIBLE PERSON

STI Help Desk (email:help@sti.nasa.gov)

19b. TELEPHONE NUMBER (include area code) 301-621-0390 

